\title{
InCorporating Financial Sector Risk into Monetary Policy Models: Application to Chile
}

\author{
Dale F. Gray \\ International Monetary Fund \\ Carlos J. García \\ Ilades-Universidad Alberto Hurtado \\ Leonardo Luna \\ Transelec, Chile \\ Jorge E. Restrepo \\ Central Bank of Chile
}

This article analyzes whether market-based financial stability indicators (FSIs) should be included in monetary policy models and, if so, how. ${ }^{1}$ Since the economy and interest rates affect financial sector credit risk, and the financial sector affects the economy, this article builds a model of financial sector vulnerability and integrates it into a macroeconomic framework, typically used for monetary policy analysis. More specifically, should the central bank explicitly include the financial stability indicator in its monetary policy (interest rate) reaction function? This is the most important question to be answered in this article. The alternative would be to react only indirectly to financial risk by reacting to inflation and gross domestic product (GDP) gaps, since they already include the effect that financial factors have on the economy. ${ }^{2}$

We thank Rodrigo Alfaro, Nicolas Magud, Jorge Chan-Lau, as well as the conference participants for useful comments and suggestions.

1. The term FSI used here is an indicator derived from forward-looking market information, including indicators from the contingent claims analysis model. It should not be confused with the accounting ratio financial stability indicators.

2 . An alternative could be designed in which the central bank only reacts directly to financial risk whenever the financial stability indicator breaches a predetermined threshold.

Financial Stability, Monetary Policy, and Central Banking, edited by Rodrigo A. Alfaro, Santiago, Chile. (c) 2010 Central Bank of Chile. 
The integration of the analysis of financial sector vulnerability into macroeconomic models is an area of important and growing interest for policymakers, in both developed and emerging markets. Monetary policy models and financial stability models, by their nature, are very different frameworks. Monetary policy models are widely used by central banks to understand the transmission mechanisms of interest rates to the macroeconomy and inflation. On the other hand, coherently estimating the effect of shocks to vulnerability on banks' risk requires both a model of banking sector risk and a tractable methodology for simulating shocks and estimating their effect on various risk measures.

Market-based financial stability indicators summarize both the credit channel and credit risk transmission from distressed borrowers in the economy. Market-based FSIs provide information on the banking sector's financial condition, which is related to the quantity of credit extended and the possible or expected effects of this channel on the real economy and GDP (that is, credit expansion and the financial accelerator). ${ }^{3}$ Market-based FSIs also capture the reduced financial soundness of banks when borrowers default in periods of economic distress, which lowers the value of risky debt and thus reduces banking sector assets and increases banking asset volatility. This is a reflection of the economic condition of borrowers and of the real economy. (Note that when the banking sector is in distress, bank assets and bank equity values are lower and the volatility of bank assets and bank equity is much higher).

Among the different choices for the market-based FSIs, in this paper we use distance to default of the banking system, which is an indicator of the riskiness of banks estimated from the contingent claims analysis (CCA) tools developed in finance. The basis of CCA is that the liabilities of a financial institution or firm derive their value from assets that are stochastic. The expected variation (volatility) of assets over a future horizon, relative to the promised payments on liabilities, provides a measure of financial distress risk. CCA methodology is frequently used to estimate the probability that an entity (in our case, banks, but also corporations or even governments) will default on its obligations. CCA's explicit

3. Bernanke, Gertler, and Gilchrist (1999) introduced financial frictions into a business cycle model, starting a fertile field of macroeconomic research. The relation of monetary policy and financial stability is discussed in Walsh (2009) and the literature surveyed therein. 
focus on risk and the probability of default or distress and its link to market prices of equity have many advantages. Equity data by nature incorporate the forward-looking expectations of the market in a way that static indicators of bank risk, such as nonperforming loan ratios and provisioning, cannot. The high frequency of observations, at least for equity and interest rate data, allows for much faster updating of risk measures than is possible with data that are available only at monthly or quarterly frequencies. The CCA financial risk indicators are calculated for individual banks and then can be aggregated into a systemwide financial stability indicator.

The CCA systemwide FSI is modeled jointly with a practical five-equation dynamic stochastic macroeconomic model used to set monetary policy. The macroeconomic model was developed at the Central Bank of Chile at the start of the implementation of fully fledged inflation targeting in 2000 (García, Herrera, and Valdés, 2002), and it closely resembles the one proposed by Berg, Karam, and Laxton (2006) as a useful toolkit applicable to the analysis of monetary policy in many small open economies. As they claim, "in the new Keynesian synthesis, there has been a convergence between the useful empirically motivated IS/LM models developed in several policymaking institutions and dynamic stochastic general equilibrium approaches that take expectations seriously and are built on solid microeconomic foundations."

The specific model used here consists of an equation for the output gap (IS), another for inflation (Phillips curve or aggregate supply), an equation for the exchange rate (interest parity condition), a yield curve relating short- and long-run interest rates, and the Central Bank reaction function (Taylor rule). Indeed, the primary tool for macroeconomic management is the interest rate set by the central bank as a reaction to the deviations of inflation from the target and the output gap (Taylor, 1993). Most equations are forward looking in the sense that they include the expected levels of the dependent variables on the right hand side.

In addition to the macroeconomic equations, we include a CCA module that interacts with the macroeconomic equations, and they affect each other in several ways. For instance, the output gap includes distance to default as an indicator of financial risk in order to analyze whether it is significant or not. Including an aggregate

4. Berg, Karam, and Laxton (2006a, p. 3). 
indicator of distance to default-and credit risk in the GDP gap equation and testing whether the coefficient is significant is a first step to get a better understanding of how financial sector credit risk affects GDP. The system is perfectly endogenous given that the interest rate and GDP influence the level and volatility of banks equity, while at the same time distance to default affects the country risk premium, GDP, and the exchange rate. The model contains a steady state to which the variables converge, thanks to the reaction of monetary authorities.

Finally, to assess the inclusion of risk indicators in the monetary authorities' reaction function, we construct efficiency frontiers mapping inflation and output volatilities after the artificial economy is hit with stochastic shocks drawn from a normal distribution. In general, we conclude that it is more efficient to include distance to default in the reaction function, because it enables the central bank to reduce the volatility of both inflation and output. Moving the policy interest rate more than is warranted by the gaps of only inflation and output is efficient because negative shocks to asset prices and liquidity could end up in a credit risk crisis, with negative systemic consequences for the financial system and production. ${ }^{5}$

Section 1 presents the background of CCA distance to default and discusses the data used in the analysis. Section 2 lays out the macroeconomic framework, as well as the equations required to simulate distance to default, which are included in the macroeconomic setting. Section 3 presents the results of the simulations, and, section 4 concludes and presents possible extensions in this line of research.

\section{Risk Measures from Contingent Claims Analysis}

This section introduces the contingent claims approach (CCA), which uses forward-looking information to build risk indicators for the banking system, and have important implications, for monetary policy, as will be clear in the third section This approach provides a methodology to combine balance sheet information with widely used finance and risk management tools to construct marked-to-market balance sheets that better reflect underlying risk. The risk-adjusted balance sheets use option pricing tools to value the liabilities, which are modeled as claims on stochastic assets. The approach can be

5. On the other hand, a very large distance to default could reflect bubbles in asset prices, which usually have bitter endings. 
used to derive a set of risk indicators, including distance to default, that can serve as barometers of risk for firms, financial sector vulnerability, and sovereign risk.

A contingent claim is any financial asset whose future payoff depends on the value of another asset. The prototypical contingent claim is an option - the right to buy or sell the underlying asset at a specified exercise price by a certain expiration date. A call is an option to buy, and a put is an option to sell; the value of each is contingent on the price of the underlying asset to be bought or sold. Contingent claims analysis is a generalization of the option pricing theory pioneered by Black and Scholes (1973) and Merton (1973). Since 1973, option pricing methodology has been applied to a wide variety of contingent claims. In this paper we focus on its application to the analysis of credit risk and guarantees against the risk of default, together with their links to macroeconomic and financial developments.

The contingent claims approach is based on three principles: the values of liabilities are derived from assets; liabilities have different priority (that is, senior and junior claims); and assets follow a stochastic process. The liabilities consist of senior claims (such as senior debt), subordinated claims (such as subordinated debt), and junior claims (equity or the most junior claim). For a bank, as the value of its total assets decline, the debt that it owes to other institutions becomes riskier, and its value declines, while the credit spreads on its risky debt rise.

Balance sheet risk is the key to understanding credit risk and the probability of crisis. Default happens when assets cannot service debt payments, that is, when assets fall below a distress barrier comprising the total value of the firm's liabilities. Uncertain changes in future asset value, relative to promised payments on debt, is the driver of default risk. Figure 1 illustrates the key relationships. The uncertainty in asset value is represented by a probability distribution at time horizon $T$. At the end of the period, the value of assets may be above the promised payments, indicating that debt service can be made, or below the promised payments, leading to default. The area below the distribution in figure 1 is the "actual" probability of default. The asset-return probability distribution used to value contingent claims is not the "actual" one, but the risk-adjusted or risk-neutral probability distribution, which substitutes the riskfree interest rate for the actual expected return in the distribution. This risk-neutral distribution is the dashed line in figure 1, with 
expected rate of return $r$, the risk-free rate. Thus, the risk-adjusted probability of default calculated using the risk-neutral distribution is larger than the actual probability of default for all assets that have an actual expected return $(\mu)$ greater than the risk-free rate $r$ (that is, a positive risk premium) ${ }^{6}$

\section{Figure 1: Distribution of Asset Value and Probability of Default}

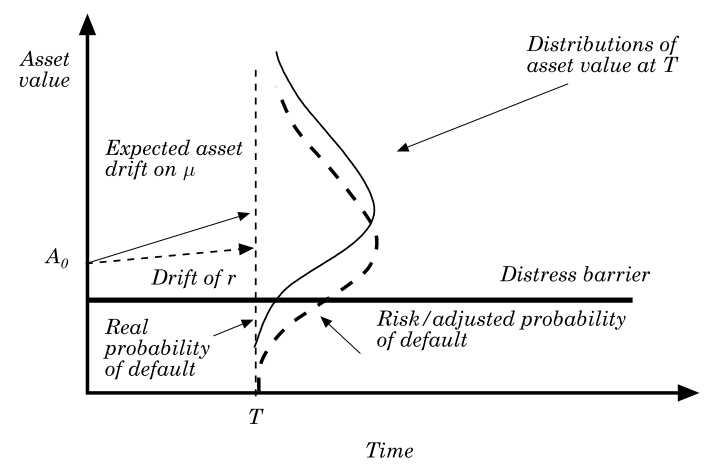

Source: Adapted from Gray and Malone (2008).

The actual probability of default can be calculated by combining the CCA/Merton model with an equilibrium model of underlying asset expected returns to produce estimates that are consistent for expected returns on all derivatives, conditional on the expected return on the asset. One does not have to know expected returns to use the CCA/Merton model for the purpose of value or risk calculations, but such data are necessary for calibrating into actual probabilities. The value of assets at time $t$ is $\mathrm{A}(t)$. The asset return process is

$$
\frac{d A}{A}=\mu_{A} d t+\sigma_{A} \varepsilon \sqrt{t},
$$

where $\mu_{A}$ is the drift rate or asset return, $\sigma_{A}$ is equal to the standard deviation of the asset return, and $\varepsilon$ is normally distributed, with zero mean and unit variance. 
Default occurs when assets fall to or below the promised payments, $B_{t}$. Therefore, $B_{t}$ is the price at which the option is exercised. The probability of default is the probability that $A_{t} \leq B_{t}$, which is

$$
\begin{aligned}
\operatorname{Prob}\left(A_{t} \leq B_{t}\right) & =\operatorname{Prob}\left\{A_{0} \exp \left[\left(\mu_{A}-\sigma_{A}^{2} / 2\right) t+\sigma_{A} \varepsilon \sqrt{t}\right] \leq B_{t}\right\} \\
& =\operatorname{Prob}\left(\varepsilon \leq-d_{2, \mu}\right) .
\end{aligned}
$$

Since $\varepsilon \sim N(0,1)$ the "actual" probability of default is $N\left(-d_{2, \mu}\right)$, where

$$
d_{2, \mu}=\frac{\ln \left(A_{0} / B_{t}\right)+\left(\mu_{A}-\sigma_{A}^{2} / 2\right) t}{\sigma_{A} \sqrt{t}}
$$

is distance to default with a drift of $\mu_{A}$ and $N(\bullet)$ is the cumulative standard normal distribution.

The probability distribution at time $T$ is shown in figure 1 above (dashed line) with drift of the risk-free interest rate, $r$. The riskadjusted probability of default is $N\left(-d_{2}\right)$, where

$$
d_{2}=\frac{\ln \left(A_{0} / B_{t}\right)+\left(r-\sigma_{A}^{2} / 2\right) t}{\sigma_{A} \sqrt{t}} .
$$

This is distance to default with a drift of $r$, the risk-free rate.

\subsection{Calculating Implied Assets and Implied Asset Volatility}

The value of assets is unobservable, but it can be implied using CCA. In the Merton model for firms, banks, and nonbank financial entities with traded equity, use equity, $E$, equity volatility, $\sigma_{E}$, and the distress barrier in the following two equations to solve for the two unknowns $A$, asset value, and $\sigma_{A}$, asset volatility (see Crouhy, Galai, and Mark, 2000). The first equation is the equation for equity, $E$, valued using the Black-Scholes-Merton formula for pricing call options:

$$
E=A \mathrm{~N}\left(d_{1}\right)-B \exp (-r \cdot t) \mathrm{N}\left(d_{2}\right)
$$


The second equation relates the volatility and value of equity to the implied volatility and value of assets (Merton 1973, 1974):

$E \sigma_{E}=A \sigma_{A} N\left(d_{1}\right)$

where $d_{2}$ was already defined and $d_{1}=d_{2}+\sigma_{A} \sqrt{t}$. Since there are two equations and two unknowns (asset value, $\mathrm{A}$, and asset volatility, $\sigma_{A}$ ), an iteration procedure is used to find the values of the unknowns. In practice, $d_{1}$ and $d_{2}$ can be calculated because they depend on $\mathrm{A}$ and $\sigma_{A}$.

Financial fragility is intimately related to the probability of default. Shocks to prices or liquidity frequently end up being converted into credit risk crises, as banks' debtors see their income flows weaken and thus run into difficulties servicing their loans to banks. Default is hard to handle in traditional macroeconomic models in part because of assumptions that usually exclude such a possibility. In addition, flow-of-funds accounts and accounting balance sheets cannot provide measures of risk exposures that are forward-looking estimates of losses. CCA, on the other hand, is a framework that explicitly includes and estimates the probability of default.

Since there is a nonzero chance of default, the value of debt is risky and therefore less than the value of risk free debt:

Risky debt + Guarantee against default $\equiv$ Risk-free debt.

The value of risky debt can therefore be modeled as the default-free value of the debt less the expected loss:

Risky debt $\equiv$ Risk-free debt - Guarantee against default.

Given that this guarantee is an asset of uncertain value, the debt can be thought of and modeled as a contingent claim.

This identity holds both conceptually and in terms of value. If the debt is collateralized by a specific asset, then the guarantee against default can be modeled as a put option on the asset with an exercise price equal to the face value of the debt. The debt holder is offering an implicit guarantee, as it is obligated to absorb the losses if there is default. However, often a third party is the guarantor, as is the case when the government guarantees the deposit liabilities of banks or the pension-benefit promises of firms. ${ }^{7}$

7. The CCA framework is an extension of Merton's models of risky debt (1974) and deposit insurance (1977). 
Using the Black-Scholes-Merton differential equation for pricing contingent claims (shown above), the value of risky debt is a function of the default-free value of debt (that is, the distress barrier) at time 0 , the asset level at time 0 , the volatility of the asset, the time horizon until the expiration date of the claim, and the risk-free interest rate. Since 1973, the Merton methodology has been applied to a wide variety of corporations and financial institutions, as well as sovereigns.

Banks do not frequently default, and regulators are likely to be less interested in the probability of such an event than they are in the possibility that bank assets will fall below a level at which the authorities might be expected to intervene. ${ }^{8}$ One useful threshold is a minimum capital threshold. This barrier would be the default barrier plus, say, 8 percent of assets. The CCA model can be used in this analysis. This model would give the distance to minimum capital as well as the distance to default. Appendix A provides some extensions of the CCA model.

\subsection{Calculating Risk Indicators for Individual Banks or Financial Institutions}

Domestic equity markets provide pricing and volatility information for the calculation of implied assets and implied asset volatility in corporate, bank, and nonbank financial institutions. The simplest method solves two equations for two unknowns, asset value and asset volatility. Details are shown in Merton (1974) and Crouhy, Galai, and Mark (2000). Levonian (1991) uses explicit option prices on bank equity to measure equity volatility and calibrate Merton models for banks. Moody's KMV has successfully applied its version of the CCA model to measure the implied asset values and volatilities and to calculate expected default frequencies (EDFs) for over 35,000 firms and financial institutions in 55 countries around the world (KMV Corporation, 1999 and 2001).

For unlisted corporate entities and banks, the relationship between the accounting information and risk indicators of companies with traded equity can be used as a guide for mapping accounting information to default probabilities and risk indicators for institutions that do not have traded equity. (An example is Moody's RiskCalc for corporate sectors in many countries and for banks in the United States.).

8. The model's condition of infrequent default was not the case for many banks in the subprime crisis. 
The CCA model for banks and financial institutions uses a time series of the daily market capitalization, the volatility of the market capitalization, and the distress barrier (derived from book values of deposits and debt) to estimate a time series of the implied market value of bank assets and asset volatility. Several useful risk indicators can be calculated for each bank or institution, including distance to default; the risk-adjusted and actual probabilities of default; the expected losses (put option) to depositors and debt holders; the potential size of public sector financial guarantees; and the sensitivity of risk indicators to changes in underlying bank assets, asset volatility, or other factors. The steps used to calculate the implied assets and asset volatility of the individual bank or financial institution, and the risk indicators, are shown in figure 2 .

\section{Figure 2. Calibrating Bank CCA Balance Sheets and Risk Indicators}

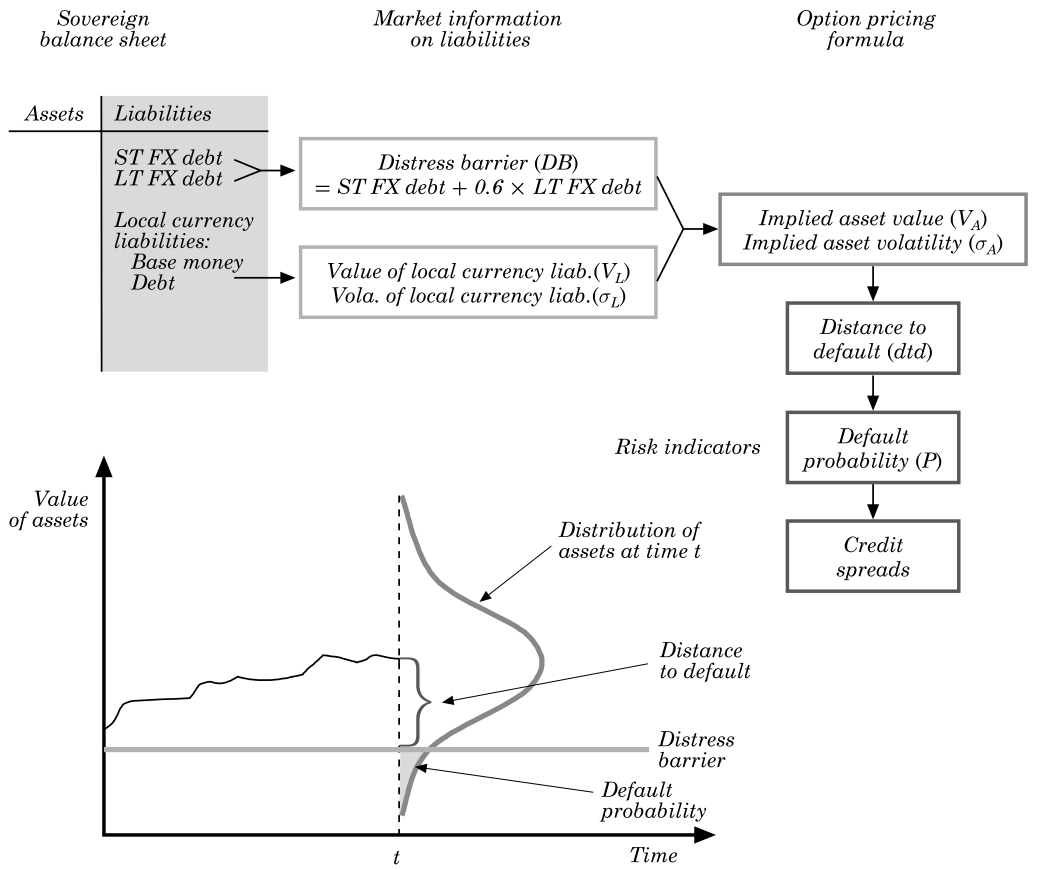

Source: Adapted from Gray and Jones (2006). 


\subsection{A Distance-to-Default Indicator for Chile}

The strategy to compute a risk indicator based on the CCA model described in the previous sections was applied for Chile. The indicator was computed by treating the portfolio of banks in the system as one large bank. Since not all banks have shares quoted in the stock market, a sample of the largest banks was used, including approximately 50 percent of total bank assets, 65 percent of the total amount of bonds issued by the banking system, and more than 80 percent of the market capitalization of the banking industry. ${ }^{9}$ The market capitalization, the volatility of the market capitalization, and the default-free value of debt (derived from book values of deposits and debt) were then used to simultaneously estimate a time series of the implied market value of bank assets and asset volatility (Gray, Echeverría, and Luna, 2007).

Although we include 80 percent of bank equity, there could be a bias given that we exclude small banks, which could be riskier. Nevertheless, when Luna and Gómez (2008) compare an aggregated risk indicator with an aggregation of individual indicators, they conclude that behavior is very similar in terms of levels and volatility. The authors further state that contagion through interbank lending would be very limited since it represents a small share of total assets. Moreover, the introduction of a real time gross settlement (RTGS) system in Chile substantially reduced settlement risks. ${ }^{10}$ Still, using ad hoc methods of aggregating data from different banks can lead to mismeasurement of systemic risk, by averaging heterogeneous agents and, implicitly, assuming that the measures of different banks' risks are not correlated. Consequently, the methodology should be used as a complement to the regular stress tests for banks and adequate surveillance analysis of the risks for banks' financial stability.

To get a daily estimate of total bank assets, an implicit value was obtained by calculating their debt and net worth. Since it is not feasible to get the market value of their short- and long-run debt, it is common to extract their book value, which, due to current regulation in Chile, is very close to the market value-provided there is no financial turmoil. Total debt includes monthly information supplied

9. See Gray, Echeverría, and Luna (2007, table 1).

10. For simplicity, we did not consider explicitely the volatility of foreign debt. Nevertheless, in Chile, banks' foreign debt in the analyzed period represented only 7 percent of total debt. 
by the Superintendency of Banks and Financial Institutions (SBIF) on short-term debt plus a portion of long-term debt. ${ }^{11}$

Nevertheless, the volatility of interest rates could imply that the market value of debt fluctuates around the book value. These fluctuations are higher for longer maturities, which in our calculation are less important. To correctly measure the market value of debt we would need to have an asset pricing model with two stochastic processes, where the interest rates affect the value of bank assets and equity. In the current setting, we are implicitly assuming that interest rates are nonstochastic. We thus have only one stochastic process, namely, bank assets.

On the equity side, daily numbers of shares and their prices for the selected banks were obtained from the Santiago Stock Exchange. However, we cannot calculate implicit equity volatility from call options on bank shares because such derivatives do not exist in Chile. We therefore obtained a direct measure of stock volatility with a simple model of conditional heteroskedasticity, with a oneyear horizon. ${ }^{12}$ Recent work on this issue shows that at least for the S\&P500, the volatility obtained with a similar model is highly correlated with the VIX, which is computed based on the implicit volatility from options on the stocks included in this index (Alfaro and Silva, 2008).

In theory, share prices should equal the present discounted value of the flow of dividends. In practice, these prices could also change as a result of many factors other than movements in fundamentals, namely, abundant liquidity, market overreactions to good news, herd behavior, or a different risk assessment than that of the authorities.

Despite all the caveats mentioned above, indicators based on the behavior of market prices have proved to be good predictors of financial stress, risk ratings, and several credit risk indicators. ${ }^{13}$ Several studies show that the model is robust, since it correctly reflects and anticipates the behavior of other measures of banks' financial fragility, such as risk ratings and various indicators of

11. A linear transformation of the balance sheet data is performed to generate daily data.

12. Echeverría, Gómez, and Luna (2008) include a detailed analysis of measuring distance to default, in which they consider alternative strategies to obtain direct volatility.

13. Tudela and Young (2003) find that the distance-to-default measure anticipates changes in the risk ratings of banks in Europe. 
portfolio quality. ${ }^{14}$ Thus, distance to default is still a very good complement to the monitoring of systemic risk.

We use the information on equity and debt to compute the implicit value of assets and its volatility with the Black-Scholes-Merton system described above, in order to solve the system of nonlinear equations for asset and asset volatility (Gray, Merton, and Bodie, 2006). However, the value of assets and their volatility require the calculation of $d_{1}$ and $d_{2}$, the latter being an exact measure of distance to default $(d t d)$. Therefore, in practice this system is complemented by two additional equations, one for $d_{1}$ and another for $d_{2}$, and solved simultaneously to obtain $A_{0}, \sigma_{A}, d_{1}, d_{2}$, as well as $N\left(-d_{2}\right)$, which corresponds to the probability of default.

An illustrative approximation to $d t d$ could be computed by defining it as the difference between the implicit market value of assets $(A)$ and the distress barrier $(D B)$, divided by one standard deviation of the value of assets: $d t d \approx(A-D B) / A \sigma_{A}$. This indicator corresponds to the number of standard deviations from the current level of assets to the distress barrier, given the level of equity and its volatility, the distress barrier, the interest rate, and the period analyzed. The larger this indicator, the safer is the banking system. It is also possible to compute the probability of default with this formula under the assumption that $d t d$ is normally distributed.

Figure 3 shows the time pattern of $d t d$ for the Chilean banking system estimated with the Black-Scholes-Merton approach from 1997 to 2006 , along with a three-month moving average. ${ }^{15}$ The period of highest risk for the banking system coincides with the fallout from the Long-Term Capital Management (LTCM) and Russian crises, between late 1998 and early 1999. Since then, the Chilean banking system has gradually reduced its risk, though this trend appears to have leveled off in late $2005 .{ }^{16}$ Other periods in which markets assessed suddenly higher risk for the Chilean banks include the

14. See Chan-Lau (2006), Chan-Lau and Gravelle (2005), and Chan-Lau, Jobert, and Kong (2004).

15. The CCA risk indicators shown in figure 3 are taken from Gray, Echeverría, and Luna (2007), who use daily market capitalization for the banks obtained by the Central Bank of Chile from the Santiago Stock Exchange. Bank debt was obtained from the Central Bank of Chile's database. Financial practitioners use various methods for estimating the volatility of daily asset returns. Two frequently used methods model daily volatility either as a GARCH $(1,1)$ or as a moving average process. The GARCH $(1,1)$ methodology for all banks in the sample was used in this case, but the results of the moving-average model are similar.

16. This leveling off has occurred at a very low level of risk, as shown below. 
decline in world stock markets following the collapse of the internet bubble in 2000 and the period preceding the Brazilian presidential elections in the third quarter of 2002.

Figure 3. Distance to Default for the Banking System

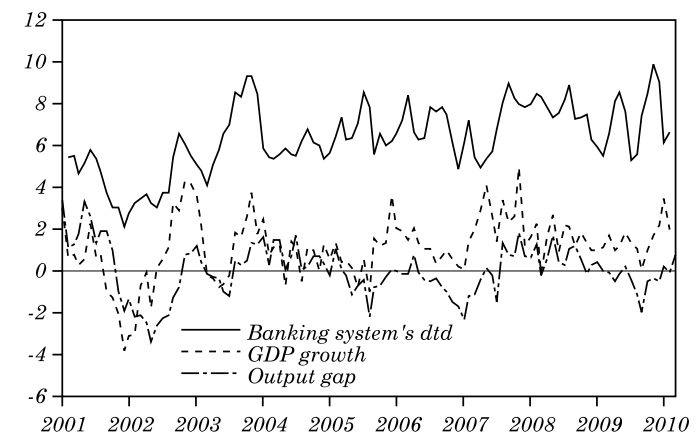

Source: Authors' calculations.

Figure 3 also illustrates that there is a relation between the banking system's distance to default and both annual GDP growth and the output gap. The regressions with output and the output gap as the dependent variable, with $d t d$ as one of the independent variables, are shown in appendix B. Distance to default has a significant impact on both output and the output gap. Other systemic risk indicators are described in detail in Gray, Merton, and Bodie (2007, 2008), Goodhart, Sunirand, and Tsomocos (2006a, 2006b), Gray and Walsh (2008), Gray and Malone (2008), Haldane, Hall, and Pezzini (2007), Segoviano (2006), and Segoviano, Goodhart, and Hofmann (2006).

\section{Linking Macrofinance Indicators to A Simple Dynamic Stochastic Macroeconomic Policy Model}

In this section, we lay out an integrated macrofinance policy model in which risk indicators for the financial system as a whole are incorporated directly into a macroeconomic policy model. Our focus here is on a modular exposition of the parts of the model and the equations that make up these parts, as well as giving intuition for how they are linked together and can be used for the analysis of a wide range of policies. 
Examples of forward-looking indicators of systemic risk derived from the contingent claim analysis (CCA) model are distance to default $(d t d)$, expected loss (that is, an implicit put option), or the default probability weighted by the assets of individual financial institutions. The macroeconomic model used here incorporates the CCA risk indicator $d t d$, whose derivation is described below. ${ }^{17}$

The first module of our model consists of equations for the most important macroeconomic variables. There is an equation for the output gap, an equation for inflation, an equation the real exchange rate, a yield curve, and a Taylor rule for setting the domestic policy rate, which is a short-term interest rate set by the central bank. The second module is used to model distance to default.

Distance to default for the banking system is included in the GDP gap equation, the parity condition, and the policy rate reaction function. The model parameters are estimated using historical data, including the distance-to-distress indicator. Although the equations have empirical support (as shown in appendix B), this is mostly a theoretical exercise in which some of the model parameters are modified (calibrated) to assess how the simulation results change with them. The approach can be used to examine the tradeoffs between GDP and inflation, with and without the inclusion of distance to distress for the banking system in the monetary authorities' reaction function. ${ }^{18}$

\subsection{Module 1: Output, Inflation, the Exchange Rate, and a Taylor Rule}

The five-equation dynamic stochastic macroeconomic model used to set monetary policy was already briefly described. This model, which is close to the one by Berg, Karam, and Laxton (2006a, 2006b), is a version of the model that was built in the Central Bank of Chile

17. A related issue is whether an indicator of market risk appetite, such as the VIX, should be included in monetary policy models along with the risk indicator. This could help estimate the impact of the credit risk indicator on the GDP gap, adjusted for changes in risk appetite. In addition, risk indicators for a group of institutions could include the correlation, or dependence structure, observed between the institutions.

18. Other interesting routes for linking risk analytics more closely with macroeconomic models include incorporating default risk and a risk premium into the Mundell-Fleming model to separate out the effects of changes in interest rates resulting from changes in the market for liquidity and from changes in the risk premium on debt (see Gray and Malone, 2009). 
at the start of the implementation of fully-fledged inflation targeting in 2000. An application of it to the design of monetary policy in Chile, using efficiency frontiers, is found in García, Herrera, and Valdés (2002). It is one example of a class of models that can be used for policy analysis in small open economies that, as stated above, are empirically motivated (IS/LM type) and at the same time share many features of the dynamic stochastic, micro-founded, general equilibrium models used by central banks. ${ }^{19}$

\subsubsection{The equation for the output gap}

The equation for the output gap is as follows:

$$
\begin{aligned}
y \operatorname{gap}_{t}= & \beta_{1} \operatorname{ygap}_{t+1}+\beta_{2} \operatorname{ygap}_{t-1}+\beta_{3} \operatorname{ygap}_{t-2}+\beta_{4} \operatorname{ygap}_{t-3}+\beta_{5}\left(r_{t-1}\right) \\
& +\beta_{6}\left(r l_{t-2}\right)+\beta_{7}\left(q_{t-4}\right)+\beta_{8}\left(d t d_{t}\right)+\varepsilon_{t}^{y},
\end{aligned}
$$

where ygap corresponds to the output gap (that is, the log deviation of GDP with respect to its trend), $r$ is the short-run real interest rate, $r l$ is the long-run real interest rate, $q$ is the real exchange rate, and $d t d$ is distance to default, which is also modeled here. As was explained in detail above, $d t d$ is a financial risk indicator that could reflect, in general, the financial conditions that the economy faces. Finally, $\varepsilon_{t}^{y}$ is a shock to GDP. All variables are expressed as log deviations from steady state.

\subsubsection{The Phillips curve}

The Phillips curve equation is

$$
\begin{aligned}
\Delta \pi_{t}= & \alpha_{1}\left[\left(\pi_{t+1}^{e}+\pi_{t}\right) / 2-\pi_{t-1}\right]+\alpha_{2}\left[\left(\pi_{t-2}+\pi_{t-3}+\pi_{t-4}\right) / 3-\pi_{t-1}\right] \\
& +\alpha_{3}\left[\left(q_{t-1}-q_{t-4}\right) / 3-\pi_{t-1}\right]+\alpha_{4}\left[\left(\operatorname{ygap}_{t-1}+y g a p_{t-2}\right) / 2\right]+\varepsilon_{t}^{\pi},
\end{aligned}
$$

where $\pi$ stands for inflation, $\pi_{t+1}^{e}$ represents inflation expectations in the next period, $q$ is the real exchange rate, and $\varepsilon_{t}^{\pi}$ is a cost-push shock.

19. See Berg, Karam, and Laxton (2006a, p. 3). 


\subsubsection{The exchange rate equation}

The exchange rate equation is equivalent to the interest parity condition:

$$
q_{t}=\delta_{1} q_{t+1}+\delta_{2} q_{t-1}+\left(r_{t}-r f_{t}\right)+\delta_{3}\left(d t d_{t-1}\right)+\varepsilon_{t}^{q} .
$$

The real exchange rate depends on lags and leads of itself, the domestic policy rate $(r)$, the foreign policy rate $(r f)$, and the risk indicator, which embeds both the sovereign spread for domestic debt and the sovereign spread for foreign debt. According to uncovered interest rate parity, the expected change in the spot exchange rate should be related to the differential between the domestic and foreign interest rates, plus some risk premium.

The long-run interest rate (yield curve) equation describes the relationship between long-run $\left(r l_{t}\right)$ and short-run $\left(r_{t}\right)$ interest rates:

$$
\left(r l_{t}\right)=\xi_{1}\left(r l_{t+1}^{e}\right)+\xi_{2}\left(r l_{t-1}\right)+\left(1-\xi_{1}-\xi_{2}\right)\left(r_{t}\right)+\varepsilon_{t}^{r l} .
$$

\subsubsection{The reaction function}

The reaction function is a Taylor rule:

$$
r_{t}=\rho\left(r_{t-1}\right)+(1-\rho)\left\{r l^{e q}+\theta\left[\begin{array}{l}
\gamma\left(\pi_{t+1}+\pi_{t}+\pi_{t-1}\right) / 3 \\
+(1-\gamma)\left(\text { ygap }_{t-1}\right)
\end{array}\right]+\zeta\left(d t d_{t}\right)\right\}+\varepsilon_{t}^{r} .
$$

The monetary policy interest rate depends on its own lag, the expected inflation gap, the output gap, distance to default, and a policy shock. While including a measure of financial stability in the Taylor rule for setting interest rates may improve efficiency (welfare), especially if financial stability affects output, accurate regulation and supervision of financial institutions could be a better way of targeting financial stability. 


\subsection{Module 2: Distance-to-Default Model for the Banking System}

This module completes the whole system to be simulated simultaneously. The value of assets, $A$, is derived from the BlackScholes model,

$$
A=\frac{E+B \cdot \exp (-r \cdot t) N\left(d_{2}\right)}{N\left(d_{1}\right)},
$$

where $E$ is the value of equity (or the value of the call option), $B$ is the value of debt in the Black-Scholes model and here also the default barrier, $r$ is the risk-free interest rate, and $t$ is time, which is fixed in the model at one year. Finally, $N($.) is the normal cumulative distribution function, and $d_{1}$ and $d_{2}$ were derived from the BlackScholes model as described in section 1.1:20

$$
d_{1}=d_{2}+\sigma_{A} \sqrt{t}
$$

and

$$
d_{2}=\frac{\ln \left(A_{0} / B_{t}\right)+\left(r-\sigma_{A}^{2} / 2\right) t}{\sigma_{A} \sqrt{t}}+d t d_{-} s h k .
$$

Note that $d_{2}$ is equal, precisely, to distance to default $\left(d t d=d_{2}\right)$.

It is apparent from equation (8) that asset volatility, $\sigma_{A}$, and assets value, $A$, are crucial for finding $d t d$. Thus, the system of nonlinear equations requires an equation for $\sigma_{A}$ if it is to yield a solution:

$$
\sigma_{A}=\frac{\left(\sigma_{E} \cdot E\right)}{\left[A \cdot N\left(d_{1}\right)\right]}
$$

where, $\sigma_{E}$ stands for volatility of equity. ${ }^{21}$

Bank equity $(E)$ and its volatility $\left(\sigma_{E}\right)$ were initially set constant, but the results obtained with the model simulations were

20. Dynare has an explicit function built in for the cumulative normal distribution function.

21. Gray and Malone (2008) provide a thorough explanation. 
counterintuitive regarding distance to default. After a cost-push shock hit the economy, inflation went up as expected, GDP fell, and the interest rate increased in reaction to the inflationary pressures. While this negative economic scenario was taking place, distance to default was growing, signaling a sounder economic situation in the banking industry and among businesses in general, which is not a sensible outcome. The efficiency frontiers obtained were not satisfactory, either. By the same token, after a positive shock to GDP, which was accompanied by an interest rate hike, distance to default fell as if the economy were more vulnerable. This is so because in the model, higher interest rates have a negative effect on the level of assets, even if the economy is in better shape.

We therefore adopted a new strategy of modeling both $E$ and its volatility, $\sigma_{E}$. As mentioned earlier, distance to default affects the macroeconomic variables in several ways: namely, by affecting GDP, the real exchange rate, and the interest rate in equations (1), (3), and (5) of the macroeconomic model, respectively. In the following equations, GDP affects banks' capital, $E$, and its volatility, $\sigma_{E}$. It also affects distance to default through this channel, making the whole system of equations completely endogenous. Another channel of endogeneity is the effect of interest rate on assets, $A$, and on the volatility of equity, $\sigma_{E}: 22$

$E_{t}=\rho E_{t-1}+0.01 \cdot \operatorname{ygap}_{t}$

$\sigma_{E}=0.1+3 \cdot\left(r_{t}\right)-\left(y g a p_{t+1}+y g a p_{t}+y g a p_{t-4}\right) / 3$.

The parameters of the macroeconomic model (see table 1) were estimated for carrying out monetary policy analysis. Although, as we said above, this is mostly a theoretical exercise in which some of the model parameters were calibrated either in the yield curve $(\xi)$ or in the reaction function $(\theta, \gamma$, and $\zeta)$, and the parameters related to distance to default were calibrated in the interest parity condition and the Phillips curve, which are used in the sensitivity analysis of the next section.

22. The spread put is an alternative measure of risk. It is described in Gray, Merton, and Bodie (2008) and Gray and Malone (2008) as a function of the value of the put option, the default barrier, the risk free rate, and time: spread_put $=-1 / t \cdot \log [1-\mathrm{PUT} / \mathrm{BB} \cdot \exp (-r \cdot t)]-0.00925382$. Although the spread put is a useful concept, it was not used in the simulations performed with the model here. 
Table 1. Parameters of the Macroeconomic Model

\begin{tabular}{ll}
\hline Parameter & \multicolumn{1}{c}{ Parameter } \\
\hline$\beta_{1}=0.1$ & $\alpha_{3}=0.05$ \\
$\beta_{2}=-0.1$ & $\alpha_{4}=0.15$ \\
$\beta_{3}=-0.6$ & $\delta_{1}=0.3$ \\
$\beta_{4}=-0.4$ & $\delta_{2}=0.6$ \\
$\beta_{5}=-0.5$ & $\delta_{3}=-0.04$ \\
$\beta_{6}=-0.5$ & $\xi_{1}=0.5$ \\
$\beta_{7}=0.02$ & $\xi_{2}=0.45$ \\
$\beta_{8}=0.2$ & $\rho=0.8$ \\
$\alpha_{1}=0.3$ & $\theta=1.3$ \\
$\alpha_{2}=0.5$ & $\gamma=0.2,0.3, \ldots, 1.2$ \\
$\alpha_{3}=0.05$ & $\zeta=0.5,1.0,1.5$ \\
\hline
\end{tabular}

Source: Authors' calculations.

\section{Stochastic Simulations and Policy Analysis}

To understand how the model works, we first obtained impulse responses (figure 4). We then assess different monetary policy alternatives and model calibrations by building efficiency frontiers with the volatilities of GDP and inflation (García, Herrera, and Valdés, 2002; Laxton and Pesenti, 2003). Specifically, we measure the responses of GDP, inflation, the exchange rate, the monetary policy interest rate, $r$, the CCA-derived risk indicator, $d t d$, and assets following a shock of 100 basis points to GDP and inflation.

Output falls after an inflation shock (cost-push shock) hits the economy, taking the output gap (ygap) to negative levels. In contrast, the interest rate tends to increase initially; when combined with the output gap reduction, this increases financial vulnerability and reduces the distance to default significantly (figure 4). The drop in the distance to default is so large that an otherwise increasing interest rate ends up falling while the exchange rate increases. This is so because the exchange rate is not only affected by the interest rate, but also by $d t d$ through the risk premium. 


\section{Figure 4. Responses to a cost-push shock to inflation $(\pi)$}

ygap

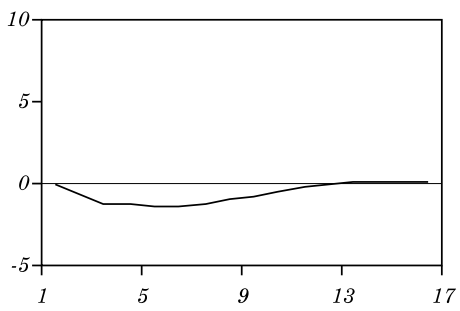

$q$
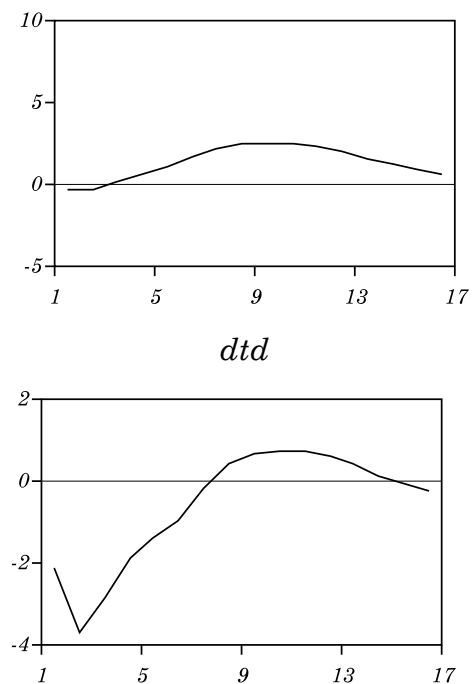

$\pi$
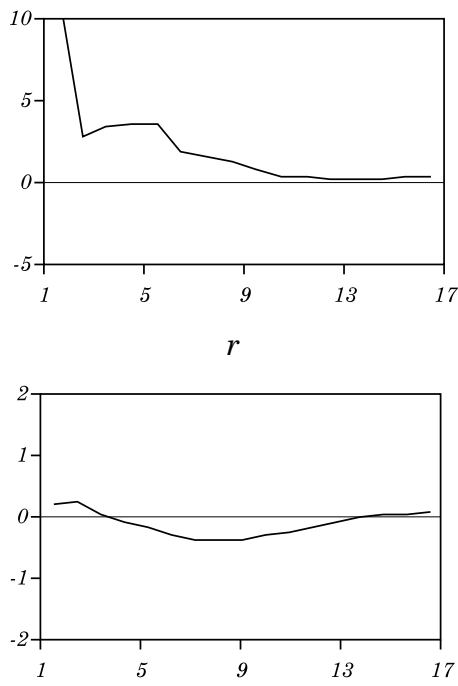

A

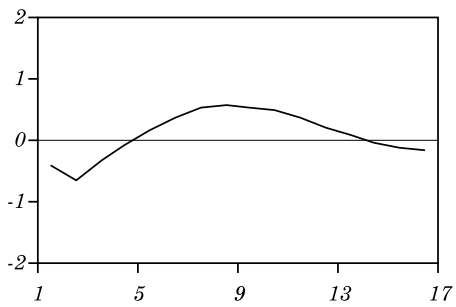

Source: Authors' calculations.

A positive shock to the output gap, in turn, causes GDP and inflation to increase. Interest rates also increase, while the exchange rate falls in line with economic intuition. The system takes around four years to return to equilibrium after the shock (figure 5). ${ }^{23}$

23. A negative shock to distance to default (not reported) causes an initial small drop in ygap, but since $d t d$ is included in the policy reaction function, the original shock is followed by a reduction in the monetary policy rate. Moreover, arbitrage through the uncovered interest parity and the respective hike of the risk premium result in a large real depreciation. Thus, the interest rate and the exchange rate fuel a GDP expansion. 
Figure 5. Responses to a shock to GDP $(y)$
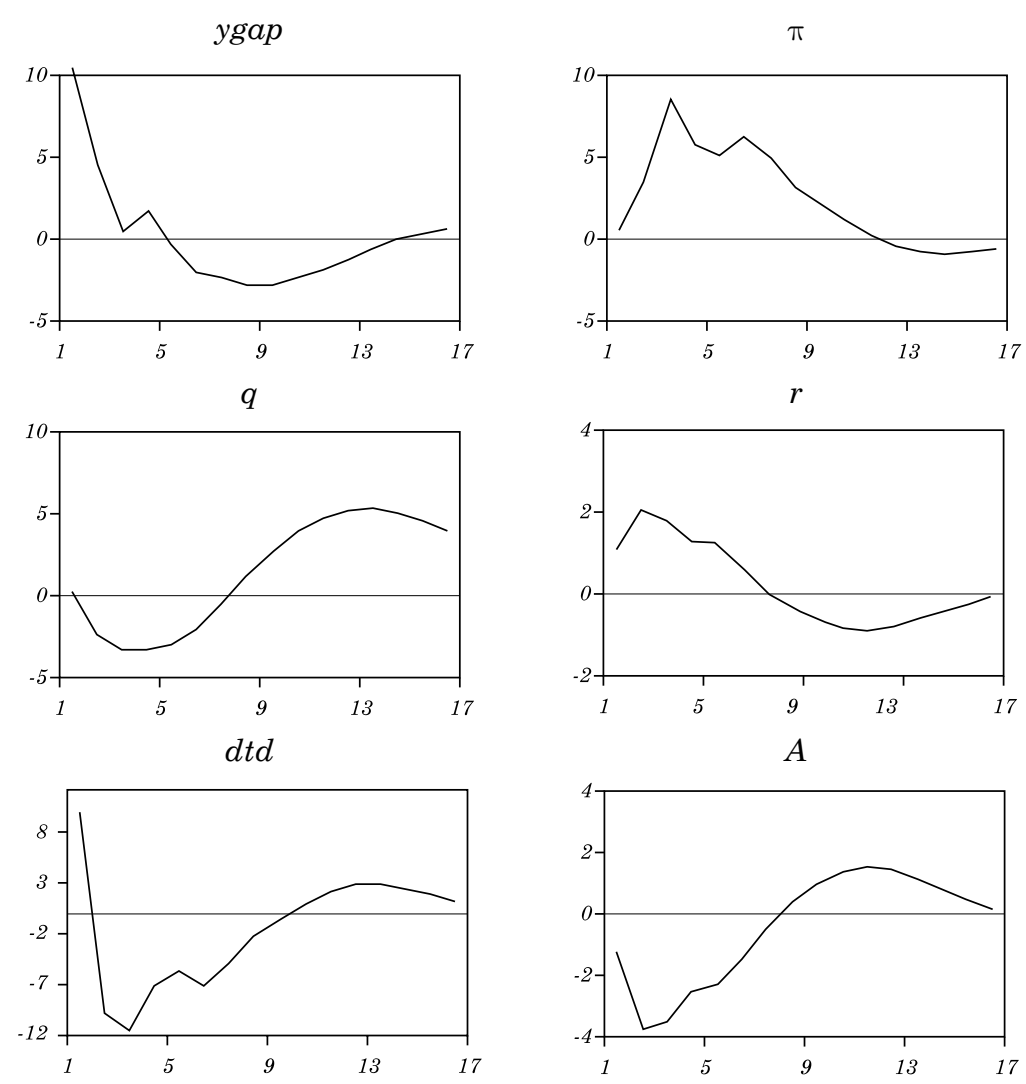

Source: Authors' calculations.

In general, the model works as expected according to standard economic intuition. There is strong interaction among macroeconomic variables, and $d t d$ has a large impact on the monetary policy rate, the real exchange rate, and even the output gap.

The efficiency frontiers are built combining the volatility of inflation and GDP that results after the economy is hit repeatedly by shocks drawn from a normal distribution. Using Dynare, we simulated the artificial economy for 200 periods, repeatedly, and computed the average standard deviations of the variables between periods 100 and 120 across the repetitions. The purpose of the exercise is to compare frontiers that were obtained with a combination of ten weights, in the policy rule, for both the inflation 
and the output gap objectives, respectively, using three different weights on distance to default. ${ }^{24}$ Additional frontiers are obtained using a similar procedure but changing one of the parameters of the model. Whenever a frontier is closer to the origin, the volatility tradeoff is smaller, and it is possible to say that the policy choice is better for the central bank and the society as a whole.

Figures 6 through 9 all include three frontiers, which were obtained with a traditional Taylor rule that includes $d t d$ in addition to inflation and GDP gaps $(\theta=0.5, \rho=0.6$, and $\gamma=0.6)$. The first line results from a rule in which $d t d$ has a small weight (with a coefficient $\zeta=0.5$ ); that is, authorities react only weakly to the risk indicator (dotted line). The other lines in the figures correspond to alternative reaction functions for monetary policy that have a larger weight of $d t d$, with coefficients $\zeta$ equal to 1.0 and 1.5, respectively (dashed and solid lines). In summary, besides reacting to inflation and GDP gaps, the monetary authority also reacts to distance to default, increasing the interest rate when $d t d$ is large, but reducing it when the banking system is close to default by more than is warranted by the inflation and output gaps alone. This is so because negative shocks to asset prices and liquidity could end up in credit risk crises, with systemic consequences for lending and production. On the other side, a very large $d t d$ could be the result of asset bubbles, which are usually associated with financial turmoil when they burst.

\subsection{Reaction Size to $d t d$ in the Policy Rule}

The size of the reaction to $d t d$ in the Taylor rule has a very significant effect on the results. Indeed, the larger the coefficient associated with $d t d$ in the authorities' reaction function, the closer to the origin is the frontier obtained with the simulations (solid line in figure 6). Therefore, the central bank's stabilization of $d t d$ contributes to stabilizing the volatilities of both GDP and inflation, which fall more with a larger coefficient on $d t d$ but with diminishing marginal gains. Increasing the coefficient from 0.5 to 1.0 generates

24. The combination of coefficients on inflation and output starts with 1.2 and 0.1 , respectively. To get the second combination, the coefficient on inflation declines, while the weight on output gap increases-both by 0.1 each time. Therefore, another point for the volatility of inflation and output would be obtained with the combination of 1.1 and 0.2 weights in the monetary policy rule. A third one would be 1.0 and 0.3 and so on, up to ten combinations. 
a large reduction in the volatility of GDP and inflation, while using a coefficient of 1.5 improves the trade-off only marginally.

Figure 6. Efficiency frontiers

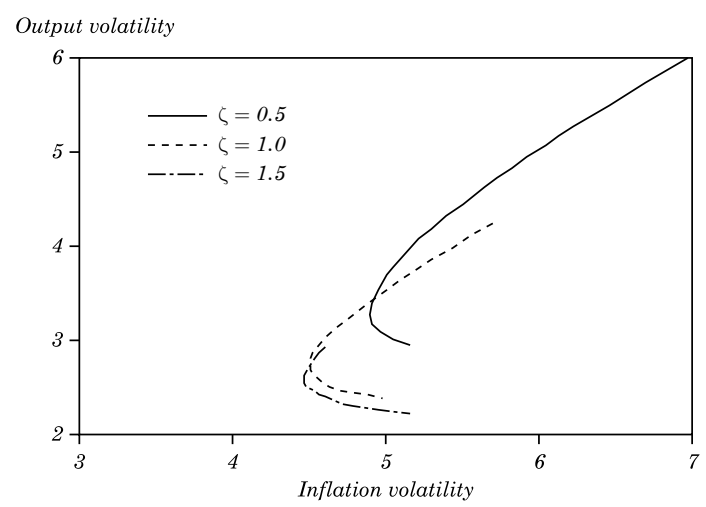

Source: Authors' calculations.

\subsection{Endogenous Effect on Bank Equity $(E)$ and Its Volatility $\left(\sigma_{E}\right)$}

This experiment consists of substantially increasing the effect of GDP on both bank equity and its volatility. This is implemented by augmenting the coefficient of ygap from 0.01 to 0.10 in equation (10) and from 1.0 to 1.5 in equation (11). If the feedback from GDP to bank equity and $d t d$ (endogeneity) is stronger, the gains by reacting strongly to $d t d$ are even larger than in the base model (figure 7). In fact, a comparison of the two panels in the figure shows that the volatility reduction of both variables, included in the frontier, is much larger here than in the base model.

\subsection{Effect of $d t d$ on the Real Exchange Rate}

In this experiment the effect (coefficient) of $d t d$ in the (risk premium) exchange rate equation (3) was increased from 0.04 to 0.50 (figure 8, panel B). Again, the solid line, which represents the frontier obtained with a larger weight on $d t d$ in the reaction function, includes points that are closer to the origin than any 
Figure 7. Efficiency Frontiers and the Endogeneity of Bank Equity

\section{A. Base model}

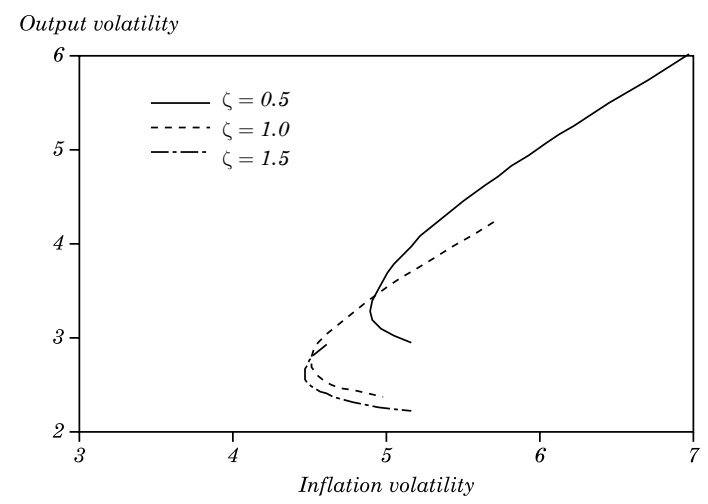

B. High endogeneity of bank equity

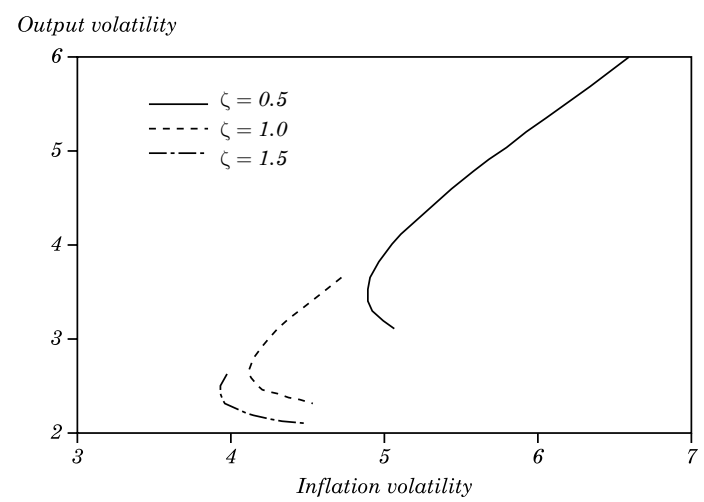

Source: Authors' calculations.

point in the dashed or dotted lines. Thus, this policy should be preferred by the central bank. The gains in terms of volatility are very similar in both panels of figure 8 , although panel B only shows small differences with respect to the baseline model. The shape of the frontiers obtained in this experiment indicates that putting more weight on inflation generates a larger reduction in inflation volatility. 
Figure 8. Efficiency Frontiers and the Interest Parity Condition

A. Base model

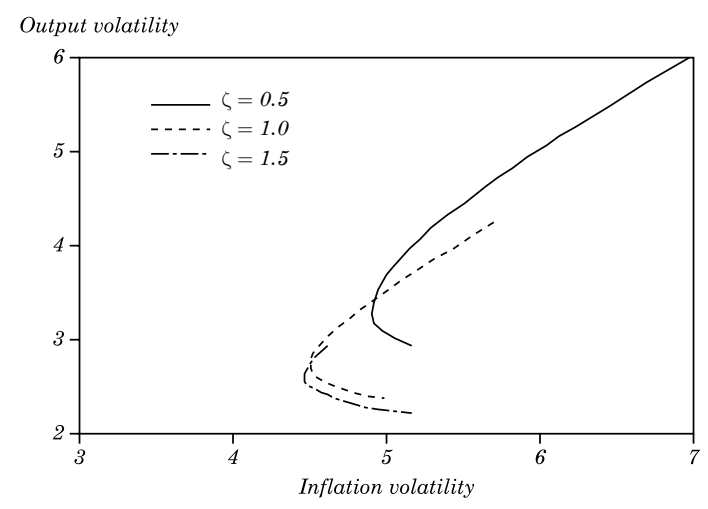

B. High effect of $d t d$ on the real exchange rate

Output volatility

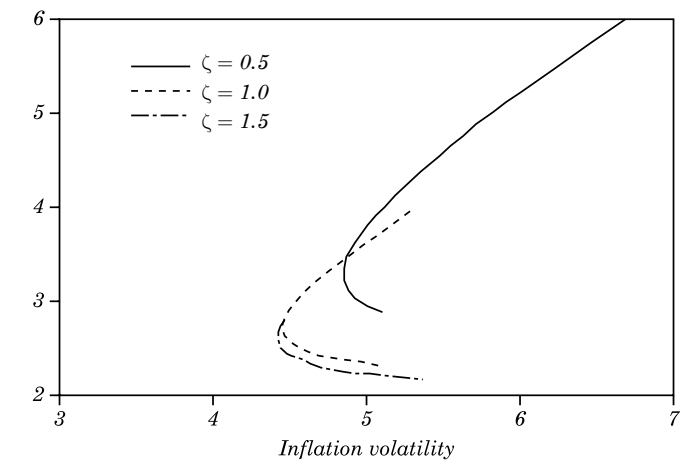

Source: Authors' calculations.

\subsection{Higher Pass-through}

Were the pass-though from exchange rate to inflation larger $(0.7$ instead of 0.05), the central bank policy would be more efficient if it reacted to $d t d$. Indeed, by reacting to $d t d$ the central bank is able to reduce volatility mostly of output. As shown in figure 9 , the frontiers move downward whenever the coefficient associated with $d t d$, in the monetary policy rule, increases. A high level of pass-through is an important issue in very open economies. If prices are very flexible 
and quickly reflect any movement of the exchange rate, it would be more difficult for relative prices to adjust after a shock, which could make GDP more volatile too.

\section{Figure 9. Efficiency Frontiers and Pass-through}

A. Base model

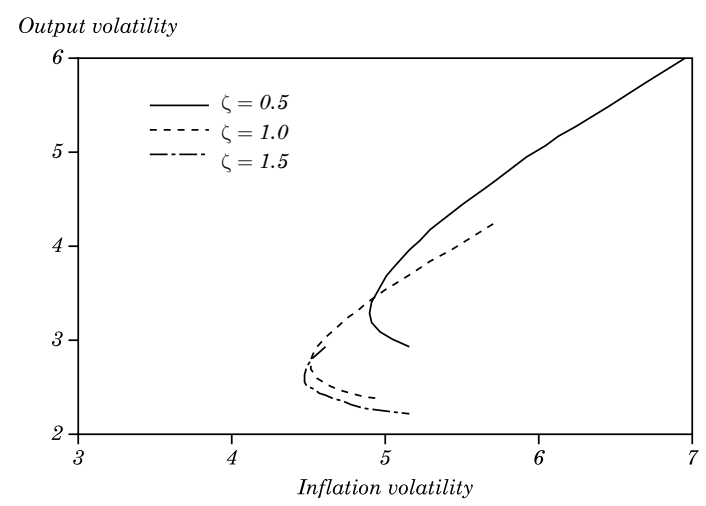

B. Higher pass-through

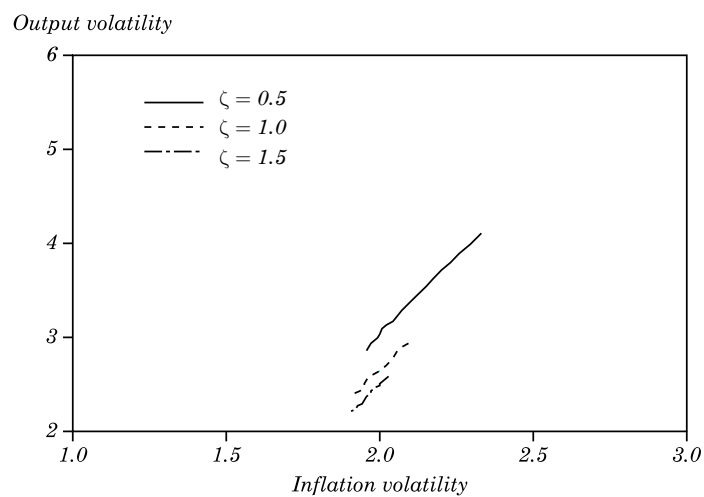

Source: Authors' calculations.

\subsection{Summary}

The simulations of the macroeconomic model show that it is more efficient for the central bank to put a larger weight on $d t d$ in the reaction function, given that inflation and output volatility decrease. Whenever pass-through from the exchange rate to prices is very high, 
including $d t d$ in the reaction function will reduce output volatility without increasing the variability of inflation. In addition, whether financial vulnerability or $d t d$ has a larger impact on the exchange rate, or GDP has a larger effect on bank equity and, through it, on $d t d$ (that is, endogeneity is high), it is more efficient to include $d t d$ in the reaction function because the central bank is then able to reduce the volatility of both inflation and output.

\section{Conclusions}

The main objective of this article was the integration of the analysis of financial sector vulnerability into macroeconomic models, which is an area of important and growing interest for policymakers in both developed and emerging markets. This paper uses contingent claims analysis tools, developed in finance, to construct financial stability indicators in a standard monetary policy model. Financial sector risk affects the economy, while the economy (GDP) and interest rates affect financial sector credit risk.

The new framework is simple, but powerful for monetary policy analysis. The model incorporates the main variables analyzed by policymakers, but it is small enough to facilitate understanding how it works. Although the system stochastically simulates an artificial economy, the empirical evidence supports the model. In addition, impulse responses behave in accordance with economic intuition.

The main question to be answered with the integrated model was whether or not the central bank should explicitly include the financial stability indicator in the interest rate reaction function. The alternative is to react only indirectly to financial risk by reacting to inflation and GDP gaps, since they already include the effect of financial factors on the economy. To reach the objective, efficiency frontiers were built with the volatility of inflation and output obtained from stochastic simulations. In general, we find that including the distance to default $(d t d)$ in the reaction function reduces both inflation and output volatility. Moving the policy interest rate more than what is consistent with the inflation and output gaps is efficient because negative shocks to asset prices and liquidity could lead to credit risk crises, with negative systemic consequences on the financial system and GDP.

We also performed a set of exercises in which some of the model parameters were calibrated to reflect and assess actual differences among economies regarding exchange rate pass-through, 
the relation between financial risk and exchange rate through the parity condition (risk premium), and the endogeneity of the financial indicator, namely, the degree in which the macroeconomic variables (GDP and interest rates) affect distance to default through bank assets, bank equity, and equity volatility. Whenever the pass-through from the exchange rate to inflation is higher, when the impact of financial vulnerability $(d t d)$ on the exchange rate is larger, and when the effect of GDP on bank equity (endogeneity) is stronger, it is more efficient to include $d t d$ in the reaction function, with a large coefficient. Finally, this is a first approximation to the subject, and considerable refinements and extensions could be introduced in the future. A non-exhaustive list includes the following: the use of other financial sector risk indicators; the inclusion of combinations of financial scenarios (strong, normal, fragile); adjustments to the dynamics of the macroeconomic model; the adoption of a more micro-founded general equilibrium macroeconomic model; and the introduction of empirical evidence for other countries or the application of the framework to other economies. All these extensions are left for future research. 


\section{Appendix A}

\section{Extensions of the Merton Model}

Numerous extensions of the original Merton model have been developed by relaxing some of its assumptions. Restrictions of the model include the following assumptions: (i) default can occur only at the maturity date of the debt; (ii) there is a fixed default barrier; (iii) there is a constant risk-free rate; and, (iv) asset volatility is constant. Cossin and Pirotte (2001) provide a good summary of extensions of the Merton model. Black and Cox (1976) extended the Merton model to relax assumptions (i) and (ii) above by introducing a "first passage time" model in which default can occur prior to the maturity of the debt if the asset falls below a specified barrier function for the first time.

Although the strict theoretical condition in the Merton model for default is that the value of assets is less than the required payments due on the debt, in the real world default typically occurs at much higher asset values, either because of a material breach of a debt covenant or because assets cannot be sold to meet the payments (that is, inadequate liquidity) or because the sovereign decides to default and induce a debt renegotiation rather than sell assets. To capture these real-world conditions for default in the model, we specify a market value of total assets at which default occurs. We call this level of assets that trigger default the distress barrier. This barrier can be viewed as the present value of the promised payments discounted at the risk-free rate. The approach used in the KMV model sets the barrier level equal to the sum of the book value of short-term debt, promised interest payments for the next 12 months, and half of long-term debt (see Crouhy, Galai, and Mark, 2000; Crosbie, 1999, 2001).

In the 1990s, the KMV model was based on the Vasicek and Kealhofer model, which has multiple layers of liabilities and several confidential features. The Moody's KMV expected default frequency (EDF) credit measure is calculated using an iterative procedure to solve for asset volatility. This distance to default was then mapped to actual default probabilities using a database of detailed real-world default probabilities for many firms. The Moody's KMV distance to default and the cumulative expected default probabilities (CEDF) are calculated as follows:

$$
D D_{K M V}=f\left[\frac{\ln \left(A_{0} / B_{t}\right)+\left(\mu_{A}-\sigma_{A}^{2} / 2\right) t}{\sigma_{A} \sqrt{t}}\right] ;
$$




$$
C E D F_{t}=f\left[D D_{K M V}(t)\right]
$$

This definition of $D D_{K M V}$ includes the real drift of the asset, $\mu_{A}$, whereas the distance to default from the Merton approach has $r$ for the asset drift. Since Moody's KMV estimates the actual default probabilities, the risk-neutral default probabilities are calculated from the correlation of the implied asset with the market, the market Sharpe ratio, and the time horizon.

The Merton model has been extended to include stochastic interest rates, as well. Shimko, Tejima, and Van Deventer (1993) include a Vasicek interest rate term structure model that relaxes assumption (iii) above, allowing the risk-free interest rate to change and including the correlation of asset return with the interest rate. There are two stochastic factors: the asset and the interest rate. This model is frequently called the STV model. Longstaff and Schwartz (1995) take the Black and Cox (1976) model and add in stochastic interest rates, similar to the way STV includes interest rates.

The CreditGrades model (Finger, 2002) includes a diffusion of a firm's assets and a first passage time default with a stochastic default barrier. The model was modified to incorporate equity derivatives (Stamicar and Finger, 2005). Recent research studies the relationship between the volatility skew implied by equity options and CDS spreads (Hull et. al. 2004). They establish a relationship between the implied volatility of two equity options, leverage and asset volatility. This approach is, in fact, another way of implementing Merton's model to get spreads and risk-neutral default probabilities directly from the implied volatility of equity options. Zou (2003) presents a similar approach using several equity options.

Financial support for liquidity and potential credit risk from the authorities is likely to be provided before the default barrier is reached. A minimum capital barrier, or simply a capital barrier, can be defined in addition to the default barrier. For instance, the default barrier plus 8 percent of the market value of assets could be used as the minimum 8 percent capital barrier. The area between the minimum capital barrier and the default barrier represents the probability of falling below minimum capital but not as far as default. The value of this area is calculated as the implicit put option below the minimum capital barrier minus the implicit default put option. We call the value of the area the capital barrier put option or capital barrier expected loss. This is particularly relevant to the 
central bank, as it is a measure of loss directly related to the liquidity support and financial support that would be needed to get the bank asset level above the minimum capital level.

Finally, contingent claims models can be used to assess systemic risk in portfolios of financial institutions, including the correlation or dependence structure among them. 
APPENDIX B

\section{Regression Results of Output and the Output Gap on the Distance to Default of the Banking System}

The first regression is on GDP growth:

$\Delta y_{t}=a+\alpha_{1} r_{t-1}+\alpha_{2} \Delta d t d_{t-1}+\alpha_{3} \Delta e_{t-1}+\alpha_{4} \Delta y_{t-1}+\varepsilon_{t}$.

The results are presented in table B1. The second is a regression on the output gap:

$\operatorname{ygap}_{t}=c+\alpha_{1} \Delta d t d_{t-1}+\alpha_{2} \Delta e_{t-3}+\alpha_{3} y_{g a p} t_{t-1}+\alpha_{4} y_{g a p}^{t-3}+\xi_{t}$.

The results are presented in B2. These regressions show that changes in $d t d$ are significant in explaining both quarterly GDP growth (the first equation) and the output gap (the second equation) with the expected positive sign.

Table B1. GDP Growth Regressions ${ }^{a}$

\begin{tabular}{lrccc}
\hline Variable & Coefficient & Standard error & t statistic & Probability \\
\hline Constant & 0.011 & 0.002 & 4.830 & 0.000 \\
$r_{t-1}$ & -0.001 & 0.000 & -3.723 & 0.000 \\
$\Delta e_{t-1}$ & 0.046 & 0.019 & 2.438 & 0.017 \\
$\Delta d t d_{t-1}$ & 0.012 & 0.003 & 3.551 & 0.001 \\
$\Delta y_{t-1}$ & 0.463 & 0.074 & 6.283 & 0.000 \\
Summary statistic & & & \\
$R$-squared & 0.574 & Log likelihood & 358.890 \\
Adjusted $R$-squared & 0.557 & Akaike information criterion & -6.677 \\
Durbin-Watson statistic & 1.912 & Schwarz criterion & -6.552 \\
\hline
\end{tabular}

Source: Authors' calculations.

a. The dependent variable is $\Delta y_{t}$. The adjusted sample covers the period from May 1998 to February 2007 and includes 106 observations (after adjustments). 


\section{Table B2. Output Gap Regressions ${ }^{a}$}

\begin{tabular}{lrccc}
\hline Variable & Coefficient & Standard error & t statistic & Probability \\
\hline Constant & -1.736 & 0.470 & -3.691 & 0.000 \\
$\Delta e_{t-3}$ & 4.134 & 1.639 & 2.522 & 0.013 \\
$\Delta d t d_{t-1}$ & 0.934 & 0.256 & 3.653 & 0.000 \\
ygap $t-1$ & 0.513 & 0.082 & 6.275 & 0.000 \\
ygap & 0.225 & 0.072 & 3.113 & 0.002 \\
Summary statistic & & & & -115.126 \\
$R$-squared & 0.661 & Log likelihood & \multicolumn{2}{c}{2.204} \\
Adjusted $R$-squared & 0.648 & Akaike information criterion & 2.328 \\
Durbin-Watson statistic & 1.842 & Schwarz criterion
\end{tabular}

Source: Authors' calculations.

a. The dependent variable is $\operatorname{ygap}_{t}$. The adjusted sample covers the period from February 1998 to February 2007 and includes 109 observations (after adjustments). 


\section{Appendix C}

\section{Extensions and Further Applications}

The central bank may expand its set of policy instruments to better accommodate its multiple objectives. Additional tools that can be used to target financial stability include the reserve requirements for banks and other measures of capital adequacy, such as the valueat-risk-based measures advocated in Basel II. A rule can be specified for targeting such a measure of capital adequacy, $C$, as follows:

$$
C_{t}=\phi_{1} C_{t-1}+\left(1-\phi_{1}\right)\left(\eta_{2} \text { ygap }_{t}+\eta_{3} \text { sigap }_{t}\right)+\varepsilon_{10, t} .
$$

The closer the parameter $\phi_{1}$ is to one, the more continuity is built into the capital adequacy requirement. As in the case of interest rates, some continuity is important, because significant changes in capital adequacy requirements, or interest rates, in a short amount of time can also potentially contribute to instability, as banks move en masse to comply with the new requirements. The second term in the above rule, which is multiplied by the coefficient $1-\phi_{1}$, allows the central bank to use capital adequacy requirements, or other variables that affect the risk profile of the banking sector, to respond to deviations of inflation, output, and financial stability from their targets. ${ }^{25}$ Because lower capital adequacy requirements stimulate lending, they may be able to contribute to higher investment that stimulates output when output is below the target. Likewise, more stringent capital adequacy requirements can help increase the financial stability indicator when it is below the target, by lowering the probability of banking sector instability or widespread defaults. Finally, the sovereign and the central bank will choose the coefficients of their decisions rules to maximize their objective functions. 


\section{REFERENCES}

Alfaro, R.A. and C.G. Silva. 2008. "Volatilidad de índices accionarios: el caso del IPSA." Cuadernos de Economía 45: 217-33.

Belmont, D. 2004. Value Added Risk Management in Financial Institutions. Hoboken, N.J.: John Wiley and Sons.

Berg, A., P. Karam, and D. Laxton. 2006a. "A Practical Model-Based Approach to Monetary and Policy Analysis: Overview." Working paper 06/80. Washington: International Monetary Fund.

. 2006b. "A Practical Model-Based Approach to Monetary and Policy Analysis: How-To Guide." Working paper 06/81. Washington: International Monetary Fund.

Bernanke, B.S., M. Gertler, and S. Gilchrist. 1999. 'The Financial Accelerator in a Quantitative Business Cycle Framework." In Handbook of Macroeconomics, vol. 1, edited by J.B. Taylor and M. Woodford. Amsterdam: Elsevier Science.

Black, F. and J. Cox. 1976. "Valuing Corporate Securities: Some Effects of Bond Indenture Provisions.” Journal of Finance 31(2): 351-67.

Black, F. and M. Scholes. 1973. "The Pricing of Options and Corporate Liabilities." Journal of Political Economy 81(3): 637-54.

Chan-Lau, J.A. 2006. "Fundamentals-Based Estimation of Default Probabilities: A Survey." Working paper 06/149. Washington: International Monetary Fund.

Chan-Lau, J.A. and T. Gravelle. 2005. "The END: A New Indicator of Financial and Nonfinancial Corporate Sector Vulnerability." Working paper 05/231. Washington: International Monetary Fund.

Chan-Lau, J.A., A. Jobert, and J. Kong. 2004. "An Option-Based Approach to Bank Vulnerabilities in Emerging Markets." Working paper 04/33. Washington: International Monetary Fund.

Cossin, D. and H. Pirotte. 2001. Advanced Credit Risk Analysis. Hoboken, N.J.: John Wiley and Sons.

Crosbie, P.J. 1999. "Modeling Default Risk." San Francisco, Calif.: KMV Corporation.

—. 2001. "Modeling Default Risk." San Francisco, Calif.: KMV Corporation.

Crouhy, M., D. Galai, and R. Mark. 2000. Risk Management. New York: McGraw Hill.

Duan, J.-C. 1994. "Maximum Likelihood Estimation Using Price Data of the Derivative Contract." Mathematical Finance 4(2): 155-67. 
2000. "Maximum Likelihood Estimation Using Price Data of the Derivative Contract." Mathematical Finance 10(4): 461-62.

Echeverría, C., G. Gómez, and L. Luna. 2008. "Robustez de estimadores de riesgo de crédito bancario usando análisis de derechos contingentes." Santiago: Central Bank of Chile.

Finger C., ed. 2002. CreditGrades Technical Document. New York: RiskMetrics Group.

Gapen, M.T., D.F. Gray, C.H. Lim, and Y. Xiao. 2005. "Measuring and Analyzing Sovereign Risk with Contingent Claims." Working paper 05/155. Washington: International Monetary Fund.

García, P., L.O. Herrera, and R. Valdés. 2002. "New Frontiers for Monetary Policy in Chile." In Inflation Targeting: Design, Performance, Challenges, edited by N. Loayza and R. Soto. Santiago: Central Bank of Chile.

Goodhart, C.A.E., P. Sunirand, and D.P. Tsomocos. 2006a. "A Model to Analyse Financial Fragility." Economic Theory 27(1): 107-42.

- 2006b. "A Time Series Analysis of Financial Fragility in the UK Banking System.” Annals of Finance 2(1): 1-21.

Gray, D.F., C. Echeverría, and L. Luna. 2007. "A Measure of Default Risk in the Chilean Banking System." Financial Stability Report, Second Half 2006. Santiago: Central Bank of Chile.

Gray, D.F. and S. Malone. 2008. Macrofinancial Risk Analysis. Hoboken, N.J.: John Wiley and Sons. . 2009. "Currency Mismatch and Exchange Rate Defense: The Role of Monetary Policy in Equilibrium Selection under Imperfect Capital Mobility and Default Risk." Washington: International Monetary Fund.

Gray, D.F., R.C. Merton, and Z. Bodie. 2006. "A New Framework for Analyzing and Managing Macrofinancial Risks of an Economy." Working paper 12637. Cambridge, Mass.: National Bureau of Economic Research.

- 2007. "New Framework for Measuring and Managing Macrofinancial Risk and Financial Stability." Working paper 13607. Cambridge, Mass.: National Bureau of Economic Research.

- 2008. "A Contingent Claims Analysis of the Subprime Credit Crisis of 2007-2008." Paper presented at the CREDIT Conference on Liquidity and Credit Risk. GRETA Asociati, Venice, 22-23 September.

Gray, D.F. and J. Walsh. 2008. "Factor Model for Stress Testing with a Contingent Claims Model of the Chilean Banking System." Working paper 08/89. Washington: International Monetary Fund. 
Haldane, A., S. Hall, and S. Pezzini. 2007. "A New Approach to Assessing Risks to Financial System Stability." Financial stability paper 2. London: Bank of England.

Hull, J., I. Nelken, and A. White. 2004. "Merton's Model, Credit Risk, and Volatility Skews." Journal of Credit Risk 1(1): 1-27.

IMF (International Monetary Fund). 2009. Global Financial Stability Report, April 2009, chap. 3, boxes 3.1, 3.3, and 3.6. Washington: International Monetary Fund.

Laxton, D. and P. Pesenti. 2003. "Monetary Rules for Small Open Emerging Economies." Journal of Monetary Economics 50(5): 1109-46.

Levonian, M. 1991. "Have Large Banks Become Riskier? Recent Evidence from Option Markets." Economic Review (Fall): 2-17. Federal Reserve Bank of San Francisco.

Longstaff, F. and E.S. Schwartz. 1995. "A Simple Approach to Valuing Risky Fixed and Floating Rate Debt." Journal of Finance 50(3): 789-819.

Merton, R.C. 1973. "Theory of Rational Option Pricing." Bell Journal of Economics 4(1): 141-83. Reprinted in Continuous-Time Finance, chap. 12, 1992, New York: Wiley-Blackwell.

- 1974. "On the Pricing of Corporate Debt: The Risk Structure of Interest Rates." Journal of Finance 29(2): 449-70. Reprinted in Continuous-Time Finance, chap. 12, 1992, New York: WileyBlackwell.

. 1977. "An Analytic Derivation of the Cost of Loan Guarantees and Deposit Insurance: An Application of Modern Option Pricing Theory." Journal of Banking and Finance 1(1): 3-11. Reprinted in Continuous-Time Finance, chap. 19, 1992, New York: WileyBlackwell.

- 1992. Continuous-Time Finance. Oxford: Basil Blackwell.

Segoviano, M.A. 2006. "Portfolio Credit Risk and Macroeconomic Shocks: Applications to Stress Testing Under Data-Restricted Environments." Working paper 06/283. Washington: International Monetary Fund.

Segoviano, M.A., C.A.E. Goodhart, and B. Hofmann. 2006. "Default, Credit Growth, and Asset Prices." Working paper 06/223. Washington: International Monetary Fund.

Shimko, D., N. Tejima, and D. van Deventer. 1993. "The Pricing of Risky Debt When Interest Rates Are Stochastic." Journal of Fixed Income 3(2): 58-65. 
Stamicar, R. and C. Finger. 2005. "Incorporating Equity Options into the CreditGrades Model." New York: RiskMetrics Group.

Taylor, J.B. 1993. "Discretion versus Policy Rules in Practice." Carnegie Rochester Series on Public Policy 39: 195-214.

Tudela, M. and G. Young. 2002. "A Merton-Model Approach to Assessing the Default Risk of U.K. Public Companies.” Working paper 194. London: Bank of England.

Walsh, C.E. 2009. "Using Monetary Policy to Stabilize Economic Activity." Paper prepared for the Economic Symposium. Federal Reserve Bank of Kansas City, Jackson Hole, Wyoming, 20-22 August.

Zou, J. 2003. "The Relationship between Credit Default Probability and Equity Options Volatility Surface." Paper presented at the Ninth Annual RISK USA Conference. Risk Magazine, Boston, June. 